\title{
Feminism in Javanese Culture: An Analysis of Gender Inequality in Alun Samudra Rasa Novel
}

\author{
Sa'adatun Nuril Hidayah $^{1}$, Slamet Subiyantoro ${ }^{2}$, Nugraheni Eko Wardhani ${ }^{3}$, and \\ Kundharu Saddhono ${ }^{4}$ \\ \{saadatun46@gmail.com¹, s.biyantoro@yahoo.co.id ${ }^{2}$, \\ nugraheniekowardani_99@yahoo.co.id ${ }^{3}$, kundharu_s@staff.uns.ac.id ${ }^{4}$ \} \\ 1,2,3,4 Universitas Sebelas Maret, Surakarta, Indonesia
}

\begin{abstract}
Women become victims of violence committed by men. Men consider themselves as the powerful ones and think that everything is in their control, so women are often degraded. The existence of inequality possibly results in gap between men and women as well as discrimination toward women. Gender inequality experienced by Javanese women is portrayed in Alun Samudra Rasa novel by Ardini Pangastuti Bn. This study was descriptive qualitative with the employment of feminist literature criticism approach on Alun Samudra Rasa novel. Feminist literature criticism was used to investigate how gender inequality toward female main character occurs in that novel. Source of primary data was a novel entitled Alun Samudra Rasa. Technique of data collection utilized literature study and interview. Technique of data analysis was content analysis combined with Feminist literature criticism approach. After analyzing the data, it is concluded that there are some forms of gender inequality toward female main character, namely subordination, stereotype, violence, and workload. These represent feminist view in Javanese society. Besides, in Javanese culture, feminist approach can be used as moral lesson for not considering women as a weak creature.
\end{abstract}

Keywords: feminism, Javanese culture, gender inequality, Alun Samudra Rasa novel, Javanese women

\section{INTRODUCTION}

Problems in which women are afflicted in almost occur in every aspects of human life such as the right in making decision, the desire to show women's existence in public space, the right to get job opportunity, the right to get education and many other problems that limit women's movement in showing their existence [1]. Someone's background can influence his/her attitude in his/her life.A difference in mindset, a social system, trust, genetic, even aspects geographical have the effect culture formation [2]. A concept of gender results in pro and contra in society, academicians, and government since past years and even now [3]. It can become the result of discrimination against women and places men higher status than women in public space [4].

Gender violence has resulted in unpleasant deeds such as murdering, torturing, and insulting women in terms of physical, psychological, sexual, and economic aspects [5]. The ministry of 
women's empowerment and child protection claims that Domestic Violence in the Household (KDRT) has more various and alarming motives and characteristics. The representation of gender inequality above becomes inseparable unity. Gender inequality is constructed in one's mind in social life lasting for a long time, so s/he does not consider it wrong [6].

Previous feminism studies rarely consider women's role in eastern culture. Feminism is always equalized to demanding equality developed in the West. Meanwhile, feminism is different in each culture. It indicates that feminism in Javanese culture cannot be compared to the western one. Javanese women are always identical to the characters of submissive and approval. These characters are always viewed as weak characteristics of Javanese women. In fact, these become their strengths. Javanese women are able to face difficulties in household, even more than that. Since Javanese women seem to have light responsibilities, in a certain condition, they are able to substitute husband's role. They are also able to be a breadwinner.

Gender inequality experienced by women is in public interest, one of which is literary work. Literary texts prioritizing gender equality will give positive impact for human life. In contrast, literary texts with gender-biased will construct patriarchy culture in society [7] [8]. Literary works are born due to human as the creature and human life as the source of inspiration [9]. The authors generally write their works based on their experiences [10]. Literature as a text is inseparable from the role of author and environment where a literary work is created [11]. All events happening in society are represented in detail and unique way with all problems in it. Many phenomena of gender and women also become the driving factors for the authors to create a literary work.

Alun Samudra Rasa novel told a story about a female character in facing various problems in her life associated with men's power. Ardini Pangastuti presented some problems in female character's life related to gender inequality. Gender inequality occurring to a female character was portrayed through a series of torture or violence physically and psychologically.

The studies on women, known as feminism studies have been conducted by previous researchers. The study on feminism conducted by Cara Wallis focused on feminism in China [12], while Michael D. Barnett, Kylie B. Sligar, Chiachih D. C. Wang investigated the influence of gender, religion affiliation, religiousness toward the acceptance of raping adults newly growing in US [13]. Another study conducted by Jeremiah, Eis on contemporary Germany feminism study, neoliberal [14]. Additionally, feminism study is also related to local culture. Each culture views feminism differently. The study on culture and feminism has been accounted by M.E. Baloyi, who underlined feminism and Loloba culture in Africa [15]. Besides, Kristen N. Jozkowski. Jacquelyn D. Wiersma-Mosley employed socialist feminism to investigate party culture dominated by men in White Greek system in American universities [16]. Nevertheless, this study will investigate feminism from Javanese culture point of view on how gender inequality conducted by men to women in Javanese culture demonstrated in Alun Samudra Rasa novel occurs.

Based on the reasons already mentioned, this study focuses on analyzing Alun Samudra Rasa novel from the perspective of gender inequality that is considered new and recently has positive responses. This analysis contributes to the strengthening of previous social analysis. Gender analysis is a critical analysis that sharpens an existing critical analysis [17]. The aim why gender inequality become the main issue is because of that values of character education are very beneficial for developing students' attitude better. Character education toward students can be conducted through a literature study [18]. 


\section{METHOD}

This study was qualitative research with using research design of content analysis. Content analysis is a technique that allows researchers to study human behavior [19]. This technique was employed to analyze male and female characters' attitude, point of view and image, in accordance with gender inequality. To describe the data, the gender approach will be applied. It dealt with analyzing, interpreting and evaluating literary works with new ways and point of views. Source of primary data employed in this study was Alun Samudra Rasa novel. Source of secondary data were obtained from informant, namely Ardini Pangastuti Bn as the author of Alun Samudra Rasa novel. Technique of data collection deployed literature study and interview. Technique of data analysis was content analysis with the combination of feminist literature criticism approach. To test data validity utilized triangulation techniques, namely triangulation of data source and theory. The stage of data analysis utilized the interactive analysis, including data reduction, data display and drawing conclusion [20].

\section{RESULT AND DISCUSSION}

Gender differences do not become a problem as long as it does not result in gender inequality. Unfortunately, these differences result in gender inequality. Gender inequality is a system and structure where men and women become victims of that system. It begins from differentiating sex of male and female, then gender inequality occurs culturally and is constructed by a local society that will give impact to women and men as unfortunate sides.

In Alun Samudra Rasa novel, almost all aspect of gender inequality is found. It is indicated from the description of a female character in literary work that is in patriarchal perspective. Alun Samudra Rasa novel describes female main character as a housewife, wife, and laborer. This character experienced gender inequality. Those kinds of gender inequality toward the female main character in Alun Samudra Rasa novel will be explained in the followings.

Intan Purnami is a woman who was born and grew up in Yogyakarta, Central Java. As she was born, her parents always taught Intan about etiquette, good manners, Based on the explanantion above, gender inequalities are manifested in various ways, including:

\subsection{Subornination}

Gendered-views can lead to subordination against women, an assumption that women are emotional and irrational, so it results in the stigma that women are unable to lead and unimportant [10]. For example, men are rational, strong, protective, and able to determine everything, while women are emotional (irrational), weak, responsible for nurturing, and obedient. Subordinating women and gender inequality develop in society [21]. According to [22] this assumption is eventually internalized very strongly and considered as something of 'taken for granted' and has a broad implication in portraying women to be more subordinated but men to be more superior.

This characterization finally positions women in a subordinate and gives women discriminative behaviors. It also results in stereotypes about women. In Alun Samudra Rasa novel, a strong stereotype is found, namely women who become servants of their husband who must be respected. It is shown in the following quotation.

"Geneya kowe ora tau gelem ngajeni marang aku, Intan? Minangka wong lanang aku tansah mbok langkahi, kerep ora kok ajak rembugan jroning njupuk keputusan-keputusan penting. Saiki kowe uga nglungani ing kalane aku mbutuhake. Kowe tansah golek 
menange dhewe lan nggugu karepe dhewe. Kaya-kaya ngedir-ngedirake dupeh kowe bisa golek dhuwit dhewe. Nanging priye-priye wae aku iki bojomu. Kudune kowe ngurmati aku lan ngajeni aku. Batine mangkel, atine kempropok." (page 78)

Translation:

However, you had never respected me, Intan? As a man, I always got unrespected behavior from you, you rarely involved me in making an important decision. Now, you also went when I needed you. You were always looking for your own win and selfish. You liked to pride yourself because you could earn a living, but, still, I was your husband. You should respect me. His heart was annoyed, tempered

In the quotation above, Intan went to her parents' house in Yogyakarta without her husband's permission. She went because she could not stand Bregas's attitude who was always jealous and rude.

\subsection{Stereotype}

Argues that stereotype is labeling or signifying a particular group [10]. It is generally related to two or more relationships and often used as an excuse to justify a certain action of a certain group over another group [23]. In Alun Samudra Rasa novel, there is a labeling of the female main character when Intan was described with harsh words and portrayed that Intan was a bad woman. It is shown as follows:

"Dasar lonthe!" Plak....! tangane Bregas mampir ing pipine Intan.

Intan nekep pipine sing krasa Njarem kena tangane sing lanang. Ning isih njarem maneh atine." (page 23)

Translation :

Lonthe! Slap...! Brengas slapped Intan's cheek.

Intan hold her sore cheek in her husband's hand. But her hearth is more broken.

From the quotation above, the word of lonthe is a label or sign of a group, it refers to a bitch or prostitute.

\subsection{Violance}

Violence generally results from different roles of gender. Men are more powerful than women. Violence against women in the household divides into four including economy, physic, psychology, and sex [22]. Explains eight types of violence due to gendered bias. They are rape, beating, and physical attacks, torture related to genital organs, violence in prostitution (economy), violence in pornography, violence in forcing sterilization in Family Planning, covert violence, and sexual harassment [17].

In Alun Samudra Rasa novel, some types of violence reveal. The most conspicuous one is physical violence such as beating. Physical violence (beating and physical attacks) were experienced by Intan, executed by her husband, namely Bregas Jatmika. The violence toward Intan is shown in the following:

"Luwih-luwih nalika tangane ngrayangi pipine sing tilas kena tangane sing lanang, sing isih nyisakake rasa lara campur panas. Dheweke rumangsa dadi wanita kang paling apes sadonya. Wong tuwane wae ora tau mara tangan, lha kok saiki wong lanang sing dipasrahi uripe tega-tegane mara tangan." (page 24)

Translation : 
Especially when she touched her slapped cheek, she still felt the pain mixed by heat. She, herself, felt to be the most unlucky woman in the world. Even her parents had never beat her or do other physical violence, but how could the man who was responsible for her life commit a violence against her.

Sexual violence is also reflected in this novel, that is Intan experienced sexual violance when her husband wanted to have a sexual intercourse with force. A sexual violance can be in force of sexual intercourse, harrasment, and rape [25].

\subsection{Workload}

Women's workloads in gendered-perspective in taking care of house and children make women bounded and responsible for domestic trifles. the assumption that women are diligent makes household chores be in charge of and responsibility of women [12]. This definitely results in a huge amount of women's workload, even twice higher than men. In general, a dual role of women refers to two or more roles that have to play by a woman at the same time. In this novel, there is a dual workload of Intan, as follows.

"Kamangka sajege dadi bojone Bregas, dheweke ora tau nuntut apa-apa marang sing lanang. Kalebu blanjan sing kudune dadi hake uga ora tau njaluk yen ora diulungi. Dudu apa-apa, nanging merga isin lan rikuh wae. Mosok blanja wae saben-saben kudu njaluk. Sing lanang mung dirah rasa pangrasane wae ben adhedhasar kesadharane dhewe kanggo ngleksanakake kewajibane minangga kepala rumah tangga. Ewa mangkono sing lanang sajake uga ora ngrumangsani” (page. 26)

Translation :

During her time as Bregas's wife, she had never demanded everything. Including her spending money that should become her right, she never asked for that unless Bregas gave her by himself. It is not like Intan was reluctant or shy to ask. Unthinkable, just some spending money have to be asked every time. She only waited for her husband's awareness to be responsible for his duty as the leader of the household, but her husband did not care about it.

In the quotation above, beside a housewife, Intan had to take care of children, work as a sports equipment employee, as well as fulfill their household needs when her husband did not give her spending money.

Javanese women have become the subjects of themselves and their body. They have their own control under themselves. Their body are no longer the object for men's pleasure. No one has the right of women's body except women themselves [26]. In a rainy day, women actually have more power because they try to maintain their pride. Basically, the courage and steadfastness of Javanese women do not appear only after modernization. It is reflected by the courage of female character in Tantri Kamandaka story who defeated the king's desire [27]. Tantri Kamandaka story is a Javanese literary work in the middle age. It indicates that the spirit of gender equality has been owned by Javanese women long before the modern era. Intan becomes a representation that Javanese women not only approve or submit to the fate but also can avoid inequality if they can use their logic. A modern woman with approval and submissive characteristics, whose position is subordinated by men, is not reflected in Intan. This is in line with Widati [28] who suggests that in the view of Javanese society life that tends to be dominantly patriarchy, there is a cultural fact in contrast to that concept [29].

Gender inequality experienced by women will greatly affect women's welfare. This has been accounted in an article entitled "representation of multiple suppression in Mirah novel from 
Banda based on postcolonial feminism perspective" that explains that the position of women's inferiority is due to the domination of colonial system of Netherland and Japan. In that era, women are placed as a maid, nyai (a low-status women who become a high one), porter, and jugun ianfu (a victim of sexual slavery) who are vulnerable to physical violence. Besides, the emergence of the indigenous role as colonial intermediary and involved agent in sexual violence made indigenous women increasingly oppressed. Hence, the existence of novels become a kind of reflection of controlling women that might exist in a different kind of behavior and place women in the lowest hierarchy among men.

\section{CONCLUSION}

From the discussion, it can be concluded that AlunSamudraRasa novel by Ardini Pangastuti Bn considerably reveals gender inequality toward female main character, Intan, executed by her husband, Bregas Jatmika. These inequalities include subordination, stereotype, violance, and workload. The view of society on women are not only based on their positions with men but also based on women's view about other women. Gender inequality and right equality must also become part of Javanese culture because each human has the same rights as $\mathrm{s} / \mathrm{he}$ was born. Women have important roles in changing the view about women as objects. Women as subjects show that domination are not only owned by men. In fact, a concept of patriarchy is not always firm. It is reflected by Intan's courage in determining her choice to cope with her problems. Javanese women represented by Intan portray that the authority on women's self and life is in women's hand.

\section{REFERENCES}

[1] Fatmariza. "Fenomena Kekerasan terhadap Perempuan di dalam Rumah Tangga," Humanus, XI (2),172-180,2012.

[2] Setyawan, B.W., \& Saddhono. K. "Ceprotan Performing Art: A Traditional Folkart Based on Urband Legend". Harmonia: Journal of Arts Research and Education, 18 (1), 67-73, 2018.

[3] Liansa,T., \&Ansari, K."Perspektif Gender dalam Dwilogi Novel Padang Bulan dan Cinta di dalam Gelas Karya Andrea Hirata: Kajian Struktur dan Kritik Sastra Feminisme serta Relevansinya sebagai Bahan Bacaan Sastra di SMA," Humanus, XV(2), 207-215, 2016.

[4] Yulisetiani, S,.Suwandi., Suyitno.,\& S. Subiyantoro. "Gender Contruction of Banyumasan Society in Perspective Prophetic Ethic on The Kubah Novel," Atlantis Press, 280, 356361, 2018.

[5] Meiliana, S.“Fenomena Kekerasan Gender Dalam Novel-Novel Karya Danielle Steel, "LITERA, 15 (1), 147-159, 2016

[6] Fakih, Mansour. “Analisis Gender dan Transformasi Sosial,” Yogyakarta: Pustaka Pelajar, 2012.

[7] Speers, S. "Gender Talk: Feminism Discourse And Conversation Analysis," London: Routledge Published, 2005.

[8] Ajala, T. "Social Construction of Gender Roles and Womens,"International Journal of Gender. 4 (2), 1-10, 2016.

[9] D.R. Pratama., S. Suwandi., \& N. E. Wardani. "Keunikan Budaya Minangkabau dalam Novel Temggelamnya Kapal Van Der Wijck Karya Hamka dan Strategi Pemasarannya dalam Konteks Masyarakat Ekonomi Asean.," Elic, 221-235, 2017. 
[10] Adnani. K., Wening Udasmoro, Ratna Noviani, "Resistensi Perempuan Terhadap TradisiTradisi Di Pesantren Analisis Wacana Kritis Terhadap Novel Perempuan Berkalung Sorban," Kawistara, 6 (2), 143-156, 2016

[11] Y. M. Raharjo., Herman J. Waluyo., \& Saddhono. K, "Kajian Sosiologi Sastra Dan Pendidikan Karakter Dalam Novel Nun Pada Sebuah Cermin Karya Afifah Afra Serta Relevansinya Dengan Materi Ajar Di SMA,” Jurnal Pendidikan Indonesia, 6 (1), 16-26, 2017.

[12] Wallis, Cara. "Gender and China's online censorship protest culture." Feminist Media Studies 15(2), 223-238, 2015.

[13] Barnett, M. D., Sligar, K. B., \& Wang, C. D. "Religious affiliation, religiosity, gender, and rape myth acceptance: Feminist theory and rape culture". Journal of interpersonal violence, 33(8), 1219-1235, 2018.

[14] Jeremiah, E. "Mad Mädchen: Feminism and Generational Conflict in Recent German literature and Film." German Quarterly, 91 (4), 508-510, 2018.

[15] Baloyi, M. E. "Paying lobola when my wife dies: An African pastoral study about thepractice of forcing people to pay lobola after their wives passed away". Journal of Human Ecology, 48(1), 135-143, 2014.

[16] Jozkowski, Kristen N., and Jacquelyn D. Wiersma - Mosley. "The Greek system: How gender inequality and class privilege perpetuate rape culture." Family relations 66 (1), 89$103,2017$.

[17] Fakih, Mansour.“Analisis Gender dan TransformasiSosial,” Yogykarta: Pustaka Pelajar. 2008.

[18] Saddhono, K. "The argumentative writing skill with multicultural awareness in indonesian language for foreign learners,"Ponte: International Scientific Researches Journal, 7 (4), 108-116, 2016.

[19] Fraenkel, Jack R., \& Norman E. Wallen, "How to Design and Evaluate Research in Education," New York: Mc Graw, 2007.

[20] Miles, M. B., \& Huberman, A. “Analisis Data Kualitatif: Buku Sumber Tentang MetodeMetode Baru”. Jakarta: Universitas Indonesia Press. 2009

[21] Purbani, W. "Watak dan Perjuangan Perempuan dalam Novel-Novel karya Penulis Perempuan Indonesia dan Malaysia Awal Abad 21 ” LITERA, 12 (2), 367-380, 2013.

[22] Sihite, Romany. "Perempuan, kesetaraan, dan Keadilan: Suatu Tinjauan Berwawasan Gender,Jakarta: PT. Raja Grafindo Persada. 2007

[23] Unsriana, L. “Diskriminasi Gender dalam Novel Ginko Karya Junichi Wanatabe, " Lingua Cultura, 8 (1), 40-47, 2014.

[24] Djannah, Fathul, dkk. "Kekerasan terhadap Istri," Yogyakarta: LkiS, 2003.

[25] Katjasungkana, N. "Aspek Hukum kekerasan terhadap perempuan dalam potret perempuan,” Permatasari, A. (Ed.). Yogyakarta: Pustaka Pelajar. 2001.

[26] Werdiningsih. Y. K. "Kekerasan terhadap Tokoh Utama Perempuan dalam Novel Kinanthi Karya Margareth Widhy Pratiwi," Atavisme, 19(1), 102-115, 2016.

[27] Widati,S. "Feminisme dalam sastra Jawa sebuah gambaran dinamika Sosial. Atavisme, 12(1), 83-96, 2009

[28] Rahayu, P., Riyadi, S., Ismiyati, S. A.,\&Susilantini, E. "Wanita dalam sastra Jawamodern: 1945-1965". Jakarta: Pusat Bahasa Departemen Pendidikan Nasional, 2003.

[29] K. Saddhono and M. Rohmadi, "A Sociolinguistics Study on the Use of the Javanese Language in the Learning Process in Primary Schools in Surakarta, Central Java, Indonesia." Int. Edu. Stu., vol. 7 no.6 pp 25-30, 2014 